\title{
Pengaruh Aplikasi Abu Terbang dan Pupuk Kotoran Sapi terhadap Populasi Mikroorganisme di Tanah Ultisol
}

\author{
The Effect of Fly Ash and Cow Manure Application on Microorganism Populations in \\ Ultisol Soils.
}

\author{
Author(s): Nurleni Kurniawati ${ }^{(1)}$ Priyadi $^{(1) *}$ \\ (1) STIPER Dharma Wacana \\ * Corresponding author: priyadigege@ymail.com
}

\begin{abstract}
ABSTRAK
Ultisol tergolong tanah kering masam yang paling luas di Indonesia tetapi minim Kata Kunci: dimanfaatkan untuk bidang pertanian. Hal ini karena kandungan $\mathrm{Al}$ yang tinggi, kurangnya unsur hara, dan rendahnya nilai $\mathrm{pH}$, sehingga perlu dilakukan perbaikan kondisi tanah. Fly ash dan pupuk kotoran sapi merupakan bahan yang dapat digunakan sebagai pembenah tanah ultisol. Fly ash merupakan limbah pembakaran batu bara dengan kandungan unsur hara dan dapat menaikkan $\mathrm{pH}$ tanah. Pupuk kotoran sapi mengandung unsur hara yang berperan dalam memperbaiki sifat biologi, kimia, dan fisika tanah. Penelitian ini bertujuan untuk mendapatkan populasi mikroorganisme tanah dengan penggunaan fly ash dan pupuk kotoran sapi sebagai pembenah tanah ultisol. Penelitian menggunakan Rancangan Acak Kelompok Lengkap yang disusun secara Faktorial kimia tanah. dengan 3 ulangan sehingga terdapat 36 satuan percobaan. Faktor pertama adalah dosis fly ash dan faktor kedua adalah dosis pupuk kotoran sapi. Variabel pengamatan berupa (total fungi, total bakteri, dan unsur kimia tanah). Hasil penelitian menunjukan bahwa penggunaan bahan pembenah tanah berupa fly ash dan pupuk kotoran sapi dapat mempengaruhi populasi mikroorganisme tanah dan sifat kimia pada tanah utisol. Populasi mikroorganisme tertinggi didapatkan pada dosis fly ash 100 t/ha dengan total populasi bakteri 7,6x105 $\pm 1,78$ Log CFU/g dan populasi fungi $17,8 \times 10^{7} \pm 1,29 \mathrm{Log} \mathrm{CFU} / \mathrm{g}$. Sedangkan dosis pupuk kandang sapi 10, 20, 30 t/ha tidak berbeda nyata pada variabel yang diamati. Penggunaan dosis fly ash 150 t/ha meningkatkan $\mathrm{pH}$ tanah mencapai 7,29, kandungan N 0,08\%, P 52,36 mg/kg, K 26,48 mg/kg, dan C-Organik sebesar 1,12\%.
\end{abstract}

\section{Keywords:}

Bacteria;

cow manure;

fly ash;

fungi;

soil chemical.

\section{ABSTRACT}

Ultisol is a marginal soil in Indonesia but its minimally utilized for agriculture. It is characteristic the high $\mathrm{Al}$, low $\mathrm{pH}$ value and low soil content, so it needs to improve soil conditions. Fly ash and cow manure are materials that can be used for repairing ultisol soil. Fly ash is a coal combustion waste containing nutrients that can be used to improve the soil. Cow manure has a nutrient tha improve soil biological, chemical and physical properties. This study to determine the population of the soil due to the application of fly ash and cow manure on marginal soils. The experiment was conducted using a completely randomized block design in a factorial. The first factor is the dosage level of fly ash and the second factor is the dose of cow manure. The results showed that the use of fly ash and cow manure as soil amendments affected the population of soil microorganisms and soil chemical properties of ultisol. The highest microorganism population was obtained at a dose of fly ash $100 \mathrm{t} / \mathrm{ha}$ with a total bacterial population of 7,6x10 $\pm 1,78 \mathrm{Log} C F U / \mathrm{g}$ and a fungal population of $17,8 \times 10^{7} \pm 1,29 \mathrm{Log} C F U / g$. While the doses of cow manure 10, 20, $30 \mathrm{t} / \mathrm{ha}$ were not significantly different in the observed variables. The use of fly ash dosage of $150 \mathrm{t} / \mathrm{ha}$ increased soil $\mathrm{pH}$ to $7.29, \mathrm{~N}$ content $0.08 \%, P 52.36 \mathrm{mg} / \mathrm{kg}, \mathrm{K} 26.48 \mathrm{mg} / \mathrm{kg}$, and Organic C by $1.12 \%$. 


\section{PENDAHULUAN}

Luas lahan kering masam sekitar 108,8 juta $\mathrm{Ha}$ atau sekitar $69,4 \%$ dari total lahan kering di Indonesia dengan jenis tanah ultisol yang mendosminasi lahan tersebut Mulyani \& Sarwani, (2013). Tanah ultisol minim dimanfaatkan untuk bidang pertanian karena memiliki karakteristik kandungan Al yang tinggi, kurangnya unsur hara, dan rendahnya nilai pH. Perlu dilakukan adanya perbaikan kondisi tanah agar lahan tersebut dapat dimanfaatkan guna mengatasi alih fungsi lahan pertanian untuk pemukiman penduduk. Perbaikan kondisi tanah atau pembenah tanah pada jenis tanah masam tersebut dapat dilakukan adanya pengapuran atau penambahan bahan organik.

Fly ash merupakan residu akhir dari pembakaran batubara yang mengandung mineral yang tidak sepenuhnya terbakar (Basu et. al., 2009). Limbah tersebut dihasilkan oleh industri besar yang setiap tahunnya semakin meningkat, tetapi penanganannya masih terbatas dan bahkan menimbulkan masalah lingkungan seperti pencemaran udara, perairan dan penurunan kualitas ekosistem (PERMENLHK, 2020). Disisi lain, fly ash dapat memperbaiki sifat fisik dan kimia tanah. Kandungan fly ash berupa $\mathrm{P}$, $\mathrm{K}, \mathrm{Ca}, \mathrm{Mg}, \mathrm{S}, \mathrm{Fe}, \mathrm{Mn}, \mathrm{Zn}, \mathrm{Cu}, \mathrm{Co}, \mathrm{B}$ dan Mo telah banyak dimanfaatkan diberbagai negara dan sektor, seperti sektor pembangunan dan pertanian pada negara Jepang, India, Indonesia, Uni Emirat Arab, dan negara berkembang lain (Bhatt et al., 2019); (Febriana et. al., 2021); (Basu et al., 2009); (Sharma \& Kalra, 2006). Penggunaan fly ash pada bidang pertanian dapat meningkatkan ketersediaan $\mathrm{P}$ dalam tanah (Kohli \& Goyal, 2010). Pemberian abu terbang (fly ash) mengandung $\mathrm{K}, \mathrm{N}, \mathrm{Zn}, \mathrm{Ca}$ dan $\mathrm{Mg}$ yang dapat meningkatkan hasil pertanian (Kishor et. al., 2010).
Pupuk kotoran sapi merupakan bahan organik yang dapat digolongkan sebagai pembenah tanah. Bahan organik tersebut dapat memperbaiki sifat fisik, kimia dan biologi tanah. Kandungan unsur hara makro pupuk kotoran sapi meliputi N, P, $\mathrm{K}, \mathrm{Ca}, \mathrm{Mg}$ dan $\mathrm{S}$ dan unsur hara mikro $\mathrm{Zn}$, $\mathrm{Cu}$, Mo, Co, B, Mn dan Fe. Kompos mengandung banyak unsur hara mikro seperti $\mathrm{Mg}, \mathrm{Co}, \mathrm{Fe}, \mathrm{N}, \mathrm{P}$, dan $\mathrm{K}$, dan dapat mempengaruhi ketersediaan air (Donn et al., 2014). Kandungan kotoran sapi yang dikomposkan mengandung $\mathrm{N} 1,4 \%$, $\mathrm{P}$ $1,6 \%, \mathrm{~K} \quad 0,8 \%$ dengan total bakteri $49,75 \times 10^{4} \mathrm{CFU} / \mathrm{mL}$ dan fungi 38,16 $\mathrm{x} 10^{11} \mathrm{CFU} / \mathrm{mL}$ menggunakan metode total plate count (TPC) (Novia et al., 2019). Pengunaan bahan organik mampu meningkatkan populasi mikrorganisme tanah dan sifat fisik-kimia seperti tanah $\mathrm{pH}$, total karbon, $\mathrm{P}$ tersedia dan kapasitas tukar kation (Wicaksono et. al., 2015). Berdasarkan uraian tersebut perlu dilakukan penelitian penggunaan fly ash dan kompos kotoran sapi sebagai pembenah tanah ultisol dengan mengetahui populasi mikroorganisme tanah dan kandungan kimia tanah.

\section{METODOLOGI}

Penelitian ini telah dilaksanakan pada Juni 2020, di Kebun Percobaan Sekolah Tinggi Ilmu Pertanian Dharma Wacana Metro yang berlokasi di Jalan Budi Utomo Kecamatan Metro Selatan Kota Metro Provinsi Lampung. Alat meliputi pot penelitian dengan volume 5 $\mathrm{kg}$, timbangan digital, pengayak tanah, alat analisis unsur kimia tanah Spektrofotometer model ICP EOS 715ES, autoclave, inkubator, laminar air flow, coloni counter, dan alat-alat gelas. Bahan penelitian meliputi fly ash, pupuk kotoran sapi, media tanam tanah ultisol, media Potato Dextrose Agar (PDA), media Nutrient Agar (NA), alkohol, dan aquades.

Penelitian menggunakan metode eksperimen menggunakan Rancangan 
Acak Kelompok Lengkap secara Faktorial dengan 3 ulangan. Sehingga terdapat 36 pot percobaan masing-masing berukuran volume $5 \mathrm{~kg}$ tanah. Faktor pertama adalah level dosis fly ash $(\mathrm{F})$ yaitu $\mathrm{f}_{0}=0 \mathrm{~g} / \mathrm{pot}(0$ $\mathrm{t} / \mathrm{ha}), \mathrm{f}_{1}=75 \mathrm{~g} / \operatorname{pot}(50 \mathrm{t} / \mathrm{ha}), \mathrm{f}_{2}=150 \mathrm{~g} / \mathrm{pot}$ (100 t/ha), dan $f_{3}=225 \mathrm{~g} /$ pot $(150 \mathrm{t} / \mathrm{ha})$ dan faktor kedua adalah dosis pupuk kotoran sapi dengan tiga taraf yaitu $\mathrm{c}_{1}=15$ $\mathrm{g} /$ pot (10 t/ha), $\mathrm{c}_{2}=30 \mathrm{~g} / \mathrm{pot}(20 \mathrm{t} / \mathrm{ha})$, dan $c_{3}=45 \mathrm{~g} /$ pot $(30 \mathrm{t} / \mathrm{ha})$.

Variabel analisis pada tanah ultisol meliputi total bakteri, total fungi, analisis kimia tanah $(\mathrm{pH}, \mathrm{C}$-organik, N-total, $\mathrm{P}$ tersedia, K). Data yang diperoleh dianalisis standar deviasi menggunakan software microsoft excel.

\section{HASIL DAN PEMBAHASAN}

Keberadaan mikroba pada tanah dipengaruhi oleh kondisi fisik, kimia, dan biologi tanah. Produktivitas dan daya dukung tanah tergantung pada aktivitas mikroorganisme tersebut. Sebagian besar mikroorganisme tanah memiliki berbagai peranan seperti menghancurkan limbah organik, siklus hara tanaman, fiksasi nitrogen, pelarut posfat, merangsang pertumbuhan, biokontrol patogen, dan membantu penyerapan unsur hara. Menurut Geoffrey, (2010) mikroorganisme tanah dapat menentukan kelarutan, mobilitas, dan ketersediaan logam bagi tumbuhan dengan mengubah nilai $\mathrm{pH}$ di lingkungan mikro tanah, spesiasi logam, dan mengekskresikan senyawa pengkhelat logam. Keseimbangan komunitas mikroba dapat meningkatkan efisiensi pemupukan sehingga produktivitas ekosistem optimum. Dengan diketahuinya kandungan C, N, P, S,dan mikroba dalam tanah dapat digunakan untuk mengukur dinamika hara (Nanipieri et al., 2017).

Perubahan kimia tanah dengan adanya penambahan fly ash ke dalam tanah mempengaruhi terjadinya perubahan populasi mikroorganisme. Populasi mikroorganisme tanah meliputi total bakteri, total fungi, yang akan berbanding lurus dengan aktivitas biologi tanah, jika total mikroorganisme tinggi maka aktivitas mikroorganisme juga semakin tinggi (Priyadi et. al., 2018).

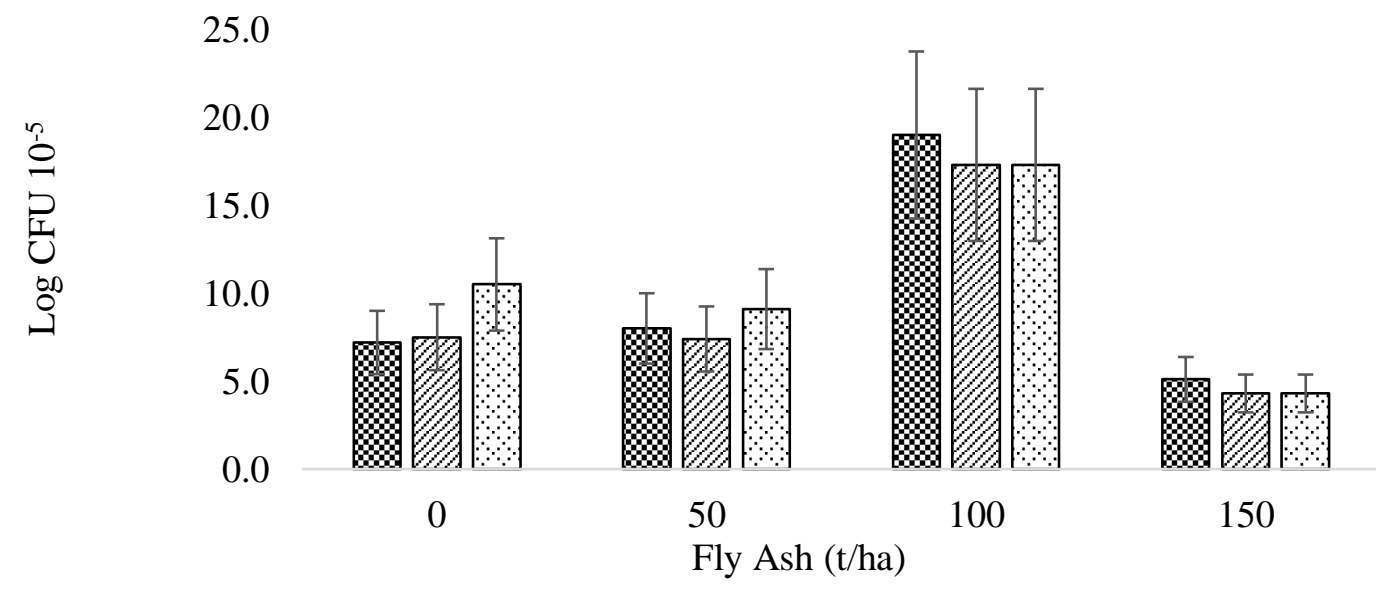

manure 10 t. ha-1

๑ Manure 20 t. ha-1

Đ. Manure 30 t. ha-1

Gambar 1. Total Bakteri Tanah Terhadap Aplikasi Fly Ash dan Pupuk Kotoran Sapi. Figure 1. Total of Soil Bacteria on Fly Ash and Cow Manure Application.

Hasil penelitian menunjukkan bahwa (Gambar 1) bahwa populasi bakteri pada tanah ultisol dipengaruhi oleh penggunaan fly ash dan pupuk kotoran 
sapi berbagai dosis. Penambahan fly ash berdampak pada meningkatnya total bakteri. Peningkatan populasi tertinggi terjadi pada penambahan fly ash $100 \mathrm{t} / \mathrm{ha}$ sebanyak $7,05 \%$ dibanding dengan tanpa fly ash dan 50 t/ha. Hal ini diduga karena adanya penambahan nutrisi, perbaikan sifat fisik, kimia tanah dari fly ash. Sedangkan dampak kimia dan biologi dari pembenah tanah dengan fly ash yaitu terjadi dari mobilitas ion kalsium dan hidroksida yang meningkat karena fluktuasi $\mathrm{pH}$. Menurut Sharma \& Kalra, (2006) menyatakan bahwa penggunaan fly ash berpengaruh terhadap peningkatan $\mathrm{pH}$ dan unsur Se, B, Mo, Al. Sejalan dengan Arthur et. al., (1984) penerapan fly ash hingga 100 t/ha di tanah dapat meningkatkan aktivitas bakteri tanah heterotropik, dan penerapan dosis lebih tinggi 400 s.d 700 t/ha dapat menurunkan mikroorganisme tanah. Diketahui penggunaan fly ash $10 \%$ menghasilkan populasi bakteri, aktivitas enzim dehidrogenase dan biomassa mikroba tanah yang tinggi dibanding dengan dosis lainnya (Kohli \& Goyal, 2010). Penelitian Gaind \& Gaur, (2004) diketahui $A$. chroococcum, A. brasilense, $P$. striata dan $B$. circulans menunjukkan pertumbuhan yang maksimal pada kombinasi aplikasi fly ash (1:1). Menurut Chetstowski et. al., (2014), dosis 50 - $800 \mathrm{mg} / \mathrm{ha}$ yang diberikan pada tanah meningkatkan pertumbuhan bakteri capiotrophic 300\% dan bakteri golongan actinomycetes sebesar $40 \%$.

Populasi bakteri dapat dipengaruhi juga oleh kandungan logam yaitu $\mathrm{Pb}$ yang terdapat pada fly ash. Diketahui transfonnasi logam berbahaya, seperti $\mathrm{Pb}$ (II) dapat terjadi pada bakteri Escherichia coli dan Pseudomonas putida. Bakteri tersebut menggunakan berbagai ion-ion logam teroksidasi seperti sebagai akseptor elektron tenninal dan menghasilkan senyawa polimer ekstraseluler (Extracellular Polymeric Substances) yaitu polisakarida, protein, asam nukleat, dan fosfolipida. Senyawa polimer ekstraseluler berperanan pada proses adhesi antarsel, adaptasi lingkungan dari ancaman, dan penguraian senyawa pencemar pada sekitar sel (Pal \& Paul, 2008). Genus Paenibacillus memiliki senyawa polimer ekstraseluler yang dapat mengikat ion $\mathrm{Cu}^{2+}$, ion-ion $\mathrm{Pb}^{2+}, \mathrm{Cd}^{2+}$. Oleh karena itu penggunaan fly ash pada berbagai dosis pada tanah ultisol memberikan pengaruh yang bervariasi terhadap mikroorganisme seperti halnya populasi bakteri antara lain actinomycetes.

Penggunaan bahan organik seperti pupuk kotoran sapi pada ultisol bertujuan untuk memperbaiki sifat fisik, kimia dan biologi tanah. Diketahui melalui grafik standar eror bahwa aplikasi pupuk kotoran sapi berbagai dosis 10, 20, 30 t/ha tidak memiliki nilai eror yang berbeda jauh terhadap populasi mikroorganisme, nilai eror yaitu $\pm 0,06-1,82$ pada bakteri dan $\pm 0,25-2,05$ untuk fungi. Hasil penelitian menunjukkan bahwa berbagai penigkatan dosis pupuk kotoran sapi memberikan peningkatan yang berbeda-beda. Peningkatan populasi mikroorganisme tertinggi terjadi pada dosis pupuk kotoran sapi $20 \mathrm{t} /$ ha dengan total populasi bakteri $7,6 \times 10^{5} \pm 1,78 \mathrm{Log} \mathrm{CFU} / \mathrm{g}$ dan populasi fungi $17,8 \times 10^{7} \pm 1,29 \mathrm{Log} \mathrm{CFU} / \mathrm{g}$ pada dosis pupuk kotoran sapi $30 \mathrm{t} / \mathrm{ha}$, sedangkang populasi terendah pada dosis $10 \mathrm{t} /$ ha yaitu bakteri $1,7 \times 10^{5} \pm 0,1 \mathrm{Log}$ $\mathrm{CFU} / \mathrm{g}$ dan fungi $4,5 \times 10^{7} \pm 0,75 \mathrm{Log} \mathrm{CFU}$ /g. Pupuk kotoran sapi dapat meningkatkan biomassa mikroba (bakteri dan jamur tanah). Pupuk kotoran kotoran sapi memiliki total fungi lebih tinggi dibanding jumlah bakteri heterotrofik. Hasil penelitian Dijkstra et. al., (2009) menemukan pada isolasi bakteri di pupuk kotoran sapi yaitu Klebsiella spp., E. coli, Serratia sp.,P. aeruginosa, Salmonella spp., Shigella sp., Sedangkan jamur yaitu Rhizopus stolonifer,A. niger, Rhodotorula spp., A. flavus. 
Peningkatan total biomassa mikroorganisme dapat disebabkan karena karbon dan unsur hara lain yang terdapat di pupuk kotoran sapi. Hasil penelitian Das et. al., (2017) melaporkan bahwa pupuk kotoran meningkatkan keanekaragaman mikroorganisme copiotrophic seperti Betaproteo bacteria, Alphaproteo bacteria, dan Firmicutes dengan spesies yang dominan yaitu $P$. oryza, A. zeae, C. alkalicellulosi, A. halopraeferens, $\quad$. caenicola, $\quad$. termitidis, C. cellulolyticum, A. rugosum, M. magnetotacticum, $P$. comonicomonovasillum, dan fungi pendegradasi selulosa, hemiselulosa, dan lignin. diketahui bahwa hasil isolasi pada pupuk kendang sapi Palu lokal terdapat beberapa jenis pengurai mikroba yaitu Lactobacillus sp, Actinomycetess pub, dan Aspergillus sp (Idham et. al., 2016)

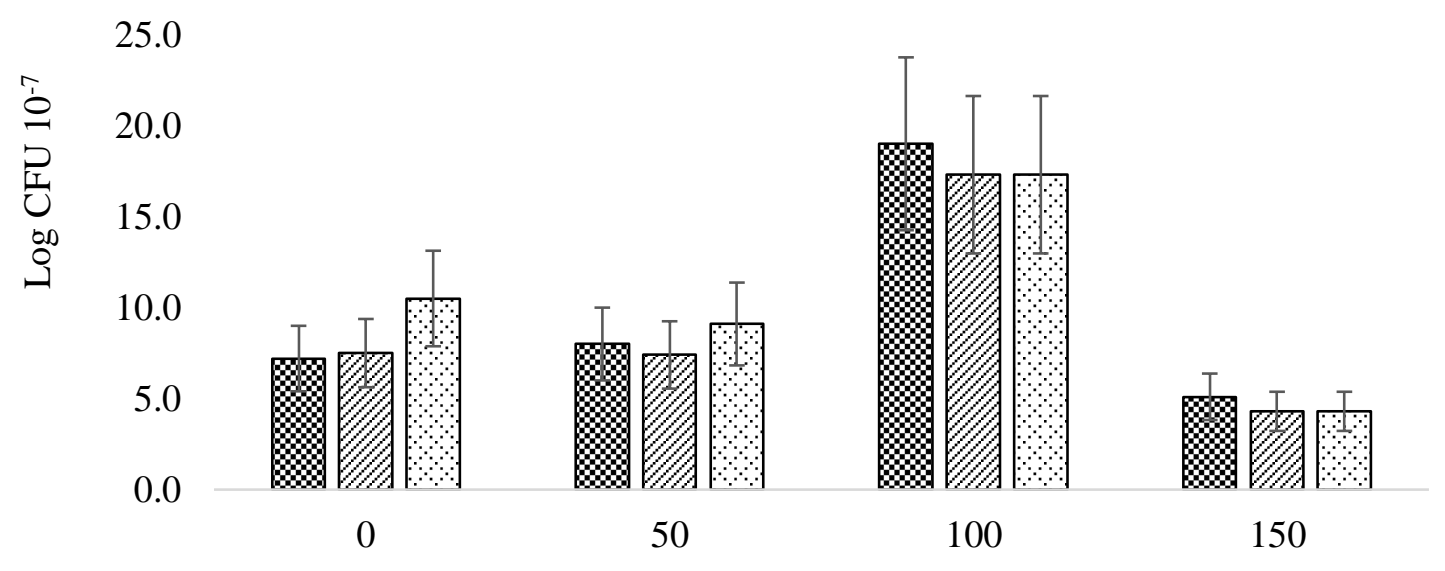

Fly Ash (t/ha)

Q Manure 10 t. ha-1

$\square$ Manure 20 t. ha-1

․ Manure 30 t. ha-1

Gambar 2. Total Fungi Tanah Terhadap Aplikasi Fly Ash dan Pupuk Kotoran Sapi. Figure 2. Total of Soil Fungi on Fly Ash and Cow Manure Application.

Gambar 2 menyatakan berbagai dosis fly ash mempengaruhi pertumbuhan fungi. Secara umum penggunaan fly ash dapat meningkatkan populasi fungi. Diketahui bahwa penggunaan dosis fly ash pada 50 t/ha pada tanah ultisol terus meningkatkna populasi fungi, dan peningkatan tertinggi terjadi pada $100 \mathrm{t} / \mathrm{ha}$ peningkatan total fungi mencapai 137,33 $\%$ jika dibandingkan dengan kontrol. Terjadi penurunan total fungi pada dosis 150 t/ha. Penelitia Gaind \& Gaur, (2004) melaporkan bahwa penggunaan fly meningkat populasi fungi $380 \times 10^{-4} / \mathrm{g}$ dengan komposisi tanah dan fly ash 1:1. Pada dosis fly ash 150 t/ha terjadi penghambatan total fungi. Hal ini diduga karena kandungan pada fly ash seperti logam, tingginya nilai $\mathrm{pH}$ serta dan salinitas residu fly ash. Menurut Chetstowski et al. (2014) aplikasi fly ash $400 \mathrm{mg} / \mathrm{ha}$ meningkatkan populasi fungi $139 \%$ dan pada dosis $800 \mathrm{mg} / \mathrm{ha}$ meningkatkan $45 \%$ lebih tinggi jika dibandingkan dengan kontrol. Mikroorganisme tanah mampu mempengaruhi lingkungannya sehingga berdampak pada tanaman dengan cara meningkatkan kelarutan, mobilitas, dan ketersediaan logam melalui pengubahan $\mathrm{pH}$, spesiasi logam, dan pengeluaran (excretion) senyawa pengkhelat logam (Anderson \& Domsch, 1993).

Menurut Shrivastava et. al., (2018), hasil isolasi jamur dari lahan yang tercemar fly ash mencapai 9 spresies dan terdapat 4 spesies yang mendominasi seperti A. niger, $C$. lunata, $P$. 
chrysogenum, Penicillium sp. and Rhizopus sp. Diketahui bahwa A. niger, A. aculeatus, A. carbonarius C. lunata, P. c5 hrysogenum, Penicillium sp., T. viride, dan $R$. stolonifera merupakan fungi yang dapat memperbaiki sifat kimia tanah yang kaya logam termasuk $\mathrm{Pb}$ dan aluminium (Makut \& Ade-ibijola, 2012). Analisis komunitas asam lemak menunjukkan peningkatan populasi jamur, termasuk jamur mikoriza arbuskular. Dengan demikian, diketahui tingginya populasi total fungi yang dapat tumbuh pada tanah ultisol, maka dapat dijadikan indikator

Tabel 1. Sifat Kimia Tanah Akibat Aplikasi Limbah Fly Ash dan Pupuk Kotoran Sapi.

Table 1. Soil Chemical Properties of Fly Ash and Cow Manure Applications.

\begin{tabular}{cccccc}
\hline \multirow{2}{*}{ Fly Ash (t/ha) } & \multicolumn{5}{c}{ Variabel Pengamatan } \\
\cline { 2 - 6 } & $\mathrm{pH}\left(\mathrm{H}_{2} \mathrm{O}\right)$ & $\mathrm{N}-$ Kjeldahl $(\%)$ & $\mathrm{P}(\mathrm{mg} / \mathrm{kg})$ & $\mathrm{K}(\mathrm{mg} / \mathrm{kg})$ & $\mathrm{C}-\mathrm{Org}(\%)$ \\
\hline 0 & $6,65 \pm 0,19$ & $0,07 \pm 0,02$ & $31,87 \pm 3,86$ & $19,59 \pm 1,19$ & $0,63 \pm 0,21$ \\
50 & $6,85 \pm 0,23$ & $0,06 \pm 0,01$ & $37,47 \pm 5,06$ & $23,37 \pm 6,90$ & $0,93 \pm 0,15$ \\
100 & $7,33 \pm 0,21$ & $0,07 \pm 0,02$ & $44,27 \pm 7,92$ & $19,06 \pm 8,05$ & $0,98 \pm 0,06$ \\
150 & $7,29 \pm 0,19$ & $0,08 \pm 0,02$ & $52,36 \pm 9,47$ & $26,48 \pm 3,58$ & $1,12 \pm 0,17$ \\
\hline
\end{tabular}

Meningkatnya nilai $\mathrm{pH}$ disebabkan adanya kandungan pada fly ash yang bersifat basa yaitu $\mathrm{Ca}$ dan $\mathrm{Mg}$. Menurut Pandey \& Singh, (2010) fly ash batubara merupakan material kompleks yang dapat meningkatkan $\mathrm{pH}$ tanah dan berfungsi seperti bahan kapur serta kaya akan silika. Selain itu penggunaan fly ash dapat meningkatkan kandungan tanah $\mathrm{P}, \mathrm{K}, \mathrm{B}$, $\mathrm{Ca}, \mathrm{Mg}, \mathrm{Mn}, \mathrm{Zn}$, karbonat, bikarbonat, dan sulfat (Khan \& Singh, 2001).

Hasil penelitian Tabel 1 diketahui bahwa terjadi peningkatan unsur N, P, dan K. Hal ini dikarenakan adanya tambahan unsur-unsur tersebut yang terkandung di dalam fly ash. Diketahui bahwa terjadi peningkatan kandungan $\mathrm{N} P$, dan $\mathrm{K}$ paling tinggi pada penambahan dosis fly ash 150 t/ha. Menurut (Mittra et. al., 2003) penggunaan fly ash dengan dosis $10 \mathrm{t} / \mathrm{ha}$ yang dikombinasikan dengan pupuk kotoran dapat meningkatkan hasil padi dan kacang tanah dengan menghemat penggunaan pupuk N,P, dan K. Penambahan fly ash yang merupakan hasil bahwa kehidupan mikroorganisme masih berlangsung.

Pada Tabel 1 menunjukkan hasil analisis kimia kombinasi limbah fly ash dan pupuk kotoran sapi bahwa terjadi peningkatan sifat kimia tanah meliputi $\mathrm{pH}$, $\mathrm{N}, \mathrm{P}, \mathrm{K}$ dan $\mathrm{C}$ organik. Semakin tinggi dosis fly ash maka semakin tinggi peningkatan terhadap semua sifat kimia tanah kecuali variabel $\mathrm{pH}$. Pada variabel $\mathrm{pH}$ terjadi penurunan pada dosis $150 \mathrm{t} / \mathrm{ha}$ dibandingkan dosis $100 \mathrm{t} / \mathrm{ha}$ namun tidak signifikan yaitu $0,14 \%$. 
pada tanah utisol. Populasi mikroorganisme tertinggi didapatkan pada dosis fly ash 100 t/ha dengan total populasi bakteri $7,6 \times 10^{5} \pm 1,78$ Log CFU /g dan populasi fungi $17,8 \times 10^{7} \pm 1,29 \mathrm{Log}$ $\mathrm{CFU} / g$. Penggunaan berbagai dosis pupuk kandang sapi 10, 20, 30 t/ha tidak berbeda pada variabel yang diamati. Penggunaan dosis fly ash 150 t/ha meningkatkan $\mathrm{pH}$ tanah mencapai 7,29, kandungan $\mathrm{N}$ $0,08 \%, \mathrm{P} 52,36 \mathrm{mg} / \mathrm{kg}, \mathrm{K} 26,48 \mathrm{mg} / \mathrm{kg}$, dan C-Organik sebesar $1,12 \%$.

\section{DAFTAR PUSTAKA}

Anderson, T. ., \& Domsch, K. . (1993). 钢 The metabolic quotient for $\mathrm{CO} 2(\mathrm{q}$ $\mathrm{CO} 2$ ) as a specific activity parameter to assess the effects of environmental conditions, such as $\mathrm{ph}$, on the microbial biomass of forest soils. Soil Biology and Biochemistry, 25(3), 393-395.

Arthur, M. F., Zwick, T. C., Tolle, D. A., EQ \& Voris, P. Van. (1984). Effects of fly ash on microbial $\mathrm{CO} 2$ evolution from an agricultural soil. Water, Air, and Soil Pollution, 22, 209-211.

Basu, M., Pande, M., Bhadoria, P. B. S., 琶 \& Mahapatra, S. C. (2009). Potential fly-ash utilization in agriculture: A global review. Prog. Nat. Sci., 19(10), 1173-1186.

Bhatt, A., Priyadarshini, S., Acharath, A., Abri, A., Sattler, M., \& Techapaphawit, S. (2019). Physical, chemical, and geotechnical properties of coal fly ash: A global review. Case Studies in Construction Materials, 11, e00263.

Chetstowski, A., Chieko, Z., \& Borowik, E. A. (2014). Effect of coal ash on the microbial and enzymatic activity in soil. Agroekologia-Artyku, 2, 32-36.
Das, S., Jeong, S. T., Das, S., Kim, P. J., Q \& Norton, J. M. (2017). Composted Cattle Manure Increases Microbial Activity and Soil Fertility More Than Composted Swine Manure in a Submerged Rice Paddy. Front. Microbiol, 8, 1-10.

Dijkstra, F. A., Bader, N. E., Johnson, D. E. W., \& Cheng, W. (2009). Soil Biology \& Biochemistry Does accelerated soil organic matter decomposition in the presence of plants increase plant $\mathrm{N}$ availability? Soil Biology and Biochemistry, 41(6), 1080-1087.

Donn, S., Wheatley, R. E., Mckenzie, B. EQ M., Loades, K. W., \& Hallett, P. D. (2014). Improved soil fertility from compost amendment increases root growth and reinforcement of surface soil on slopes. Ecological Engineering, 71, 458-465.

Febriana, S., Priyadi, \& Taisa, R. (2021). EQ Pengaruh Aplikasi Abu Terbang Batubara dan Pupuk Kandang Sebagai Bahan Amelioran Terhadap Pertumbuhan Tanaman Kangkung (Ipomea Reptans Poir.). J. Agrotek. Tropika, 9(1), 161-169.

Gaind, S., \& Gaur, A. C. (2004). EQ Evaluation of fly ash as a carrier for diazotrophs and phosphobacteria. Biomass and Bioenergy, 95, 187190.

Geoffrey, M. . (2010). Metals, minerals 的 and microbes : geomicrobiology and bioremediation. Microbiology, 156, 609-643.

Hermawan, A., Sabaruddin, Marsi, \& 理 Hayati, R. (2013). Status Jerapan dan Ketersediaan P Abu Terbang Batubara Akibat Penambahan 
Kotoran Ayam. Prosiding Seminar Nasional Lahan Suboptimal "Intensifikasi Pengelolaan Lahan Suboptimal Dalam Rangka Mendukung Kemandirian Pangan Nasional," 245-255.

Idham, Sudiarso, Aini, N., \& Nuraini, Y. 程 (2016). Isolation and identification on microorganism decomposers of Palu local cow manure of Central Sulawesi , Indonesia. J. Degrade. Min. Land Manage, 3(4), 625-629.

Khan, M. R., \& Singh, W. N. (2001). EQ International Journal of Pest Management Effects of soil application of fly ash on the fusarial wilt on tomato cultivars. International Journal OfPest Management, 47(4), 293-297.

Kishor, P., Ghosh, A. ., \& Kumar, D. 的 (2010). Use of Flyash in Agriculturae: A Way to Improve Soil Fertility and its Productivity. Asian Journal of Agricultural Research, 4(1), 1-14.

Kohli, S. ., \& Goyal, D. (2010). Effect of E fly ash application on some soil physical properties and microbial activities. Acta Agrophysica, 16(2), 327-335.

Makut, M. ., \& Ade-ibijola, O. . (2012). 尌 Citric acid producing fungi found in the soil environment of Keffi metropolis , Nasarawa state ,. International Research Journal of Microbiology, 3(7), 240-245.

Mittra, B. N., Karmakar, S., Swain, D. K., \& Ghosh, B. C. (2003). Fly Ash - a Potential Source of Soil Amendment and a Component of Integrated Plant Nutrient Supply System. International Ash Utilization
Symposium, 5, 28-35.

Mulyani, A., \& Sarwani, M. (2013). 住 Karakteristik dan Potensi Lahan Sub Optimal untuk Pengembangan Pertanian di Indonesia. Jurnal Sumber Daya Lahan, 7(1), 47-55.

Nanipieri, P., Ascher, J., Ceccherini, M. .,

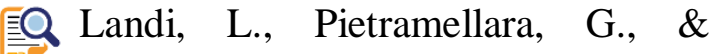
Renella, G. (2017). Microbial diversity and soil functions. Eropean Jo, 12-26.

Novia, D., Rakhmadi, A., Purwati, E., 琶 Juliyarsi, I., Hairani, R., \& Syalsafilah, F. (2019). The characteristics of organic fertilizer made of cow feces using the Indigenous Micro-Organisms (IMO) from raw manures. International Conference on Animal Production for Food Sustainability, 1-9.

Pal, A., \& Paul, A. K. (2008). Microbial EQ extracellular polymeric substances: central elements in heavy metal bioremediation. Indian J Microbiol, 48, 49-64.

Pandey, V. C., \& Singh, N. (2010). Impact EQ fly ash incorporation in soil systems. Agriculture, Ecosystems and Environment, 136(1-2), 16-27.

PERMENLHK. Penyimpanan Limbah 悬 Bahan Berbahaya dan Beracun. , Pub. L. No. P.12/MENLHK/SETJEN/PLB.3/5/20 20, 1 (2020).

Priyadi, Kurniawati, N., \& Nugroho, P. . EQ (2018). Aktivitas Biologi Tanah yang Berasal dari Perkebunan Karet pada Berbagai Kondisi Kelengasan. EnviScience, 2(1), 10-15.

Sharma, S. K., \& Kalra, N. (2006). Effect 
of flyash incorporation on soil properties and productivity of crops : A review aspects of flyash for its application in agriculture . Journal of Scientific \& Industrial Research, 65(5), 383-390. 